\title{
Competitiveness of Vietnam's Financial Institutions in the Global Financial Market: The case of Vietnam's Commercial Banks
}

\author{
NGUYEN THANH PHONG
}

University of Economics HCMC - phongnt@ueh.edu.vn

\section{ARTICLE INFO ABSTRACT}

Article history:

Received:

Dec. 152014

Received in revised form:

Dec. 252015

Accepted:

Dec. 302015

\section{Keywords:}

Commercial banks, bank

size, bank

competitiveness, $\mathrm{P}-\mathrm{R}$

model.
Using panel data collected from financial statements of 28 commercial banks in Vietnam, this paper investigates their competitiveness through an analysis of such a few elements as bank size, technological level, human resources quality, and managerial level. For a more objective evaluation the paper employs the Panzar-Rosse (P-R) model along with the use of some common econometrical techniques like Pooled OLS, FEM, REM, GLS, and H-statistic. The results show that the overall competitiveness of these banks is higher, compared to the pre-crisis period of 2008-2009. The monopolistic competition among them are also found, together with certain improvements in bank competitiveness, observed through increased bank size, enhanced human resources quality, better technological advances, and higher levels of managerial skills in compliance with international standards. 


\section{Introduction}

Integration among Vietnam's banking institutions is perceived as both an opportunity of commercial banks' access to modern technologies for improving their performance, and a challenge amid increasingly fierce competition. When the legal barriers were removed along with each free trade agreement such as the Trans-Pacific Partnership (TPP) Agreement or the ASEAN Economic Community Agreement (AEC), these events would pose greater challenges to the banking system since the signing of numerous international trade agreements is often associated with more penetration of foreign financial institutions into the national market. According to SBV's statistics, there have been operations of about 49 foreign bank branches, over 51 representative offices, five wholly foreign-owned banks and four joint-venture banks as of December 2015. Moreover, a potential growing market like Vietnam's offers many favorable conditions for the development of banking services; thus, more and more foreign counterparts have been well prepared for the expansion into the country.

Although some progress has been made over the past years, sustainable development in the course of integration requires that banks adopt sound strategies to enhance their competitiveness. Yet, unhealthy competition will adversely affect sustainable long-term growth of the whole banking system in particular and economic development in general. Therefore, to improve bank competitiveness along with healthy development of the sector, bank managers are supposed to deeply penetrate the environment where they come into operation, which allows for strategic and practical solutions.

\section{Review of literature on bank competition and competitiveness}

\subsection{Competition and bank competition}

Competition is a bitter rivalry or fierce struggle between capitalists in search of favorable conditions in goods production and consumption in order to make superprofits. For a business the competition is the most efficient use of resources or the seizure of business opportunities to gain advantage over others in its activities.

Bank competition may refer to a bank's using resources effectively or having comparative advantage to achieve domination over others in banking activities.

Commercial bank competition has the following characteristics: (i) sensitive to volatilities of domestic and international financial markets; (ii) strongly affected by 
monetary policy of a specific country; (iii) received with limited autonomy in competitiveness; and (iv) scarcely reflecting divergence of products and/or services.

\subsection{Bank competitiveness}

Competitiveness in banking activities can be defined as the bank's ability to use banking resources effectively and establish proper controls over business opportunities so as to gain maximum profits. Overall competitiveness is composed mainly of financial, technical, technological, and managerial capabilities.

According to Porter (1980), bank competitiveness depends on the following factors: (i) bank-specific factors, such as personnel (quality, skills), levels, capital, etc.; (ii) demand for banking services; (iii) bank development strategies; (iv) supervision mechanism for banking activities; and (v) development of supporting areas.

\subsection{Criteria for assessing bank competitiveness}

Quantitative criteria include bank size (total assets, equity capital), asset quality (adequacy ratio, nonperforming ratio), and other ratios (ROA, ROE, NIM, TRA, TIA, etc.)

Qualitative criteria comprise banking products, technological level, human resources quality, managerial capability, and banking brand.

\section{Evaluation of bank competitiveness in Vietnam}

\subsection{Total assets}

Total assets of the Vietnamese commercial banking system have been on the increase over the years, but reveal a slower pace of increase (the highest of 53\% as of 2007 and the lowest of 5\% as of 2012). Stable growth rate can be observed with large-sized banks, whereas small-sized ones still face obstacles to increasing their capital sources to implement the policy on integration and bank restructuring. 


\section{Total asset growth}

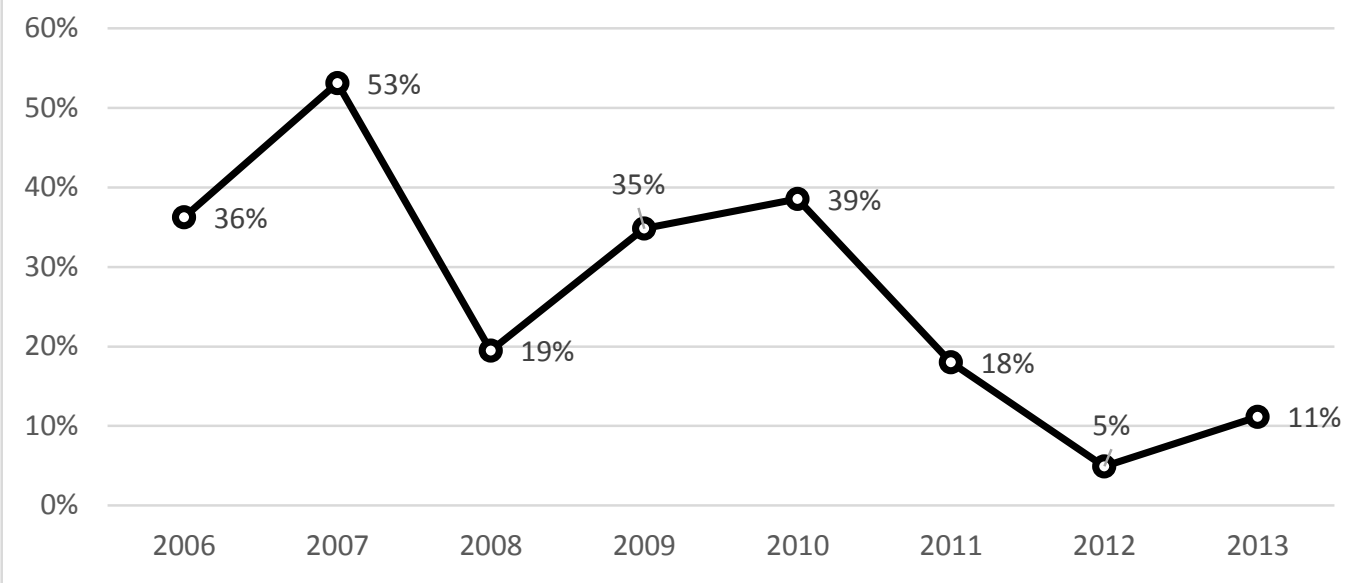

Figure 1. Increase in total assets among Vietnam's banking institutions

Source: Bankscope database

Commercial banks in Vietnam are derived from state-owned banks, accounting for a large group of banks although their size is much smaller than that of banking institutions in the region and the world (Tables 1 and 2). Enhancing bank competitiveness and financial capability for the period of 2015-2020 demands continuous increase in bank size.

\section{Table 1}

Total assets of several large-sized banks (in VNDbil.)

\begin{tabular}{lccccc}
\hline Name of bank (in abbr.) & 2010 & 2011 & 2012 & 2013 & 2014 \\
\hline Agribank & 530.71 & 556.27 & 614.37 & 695.71 & 765.28 \\
Vietinbank & 367.73 & 460.42 & 503.53 & 576.37 & 661.13 \\
BIDV & 361.95 & 399.31 & 478.83 & 542.06 & 650.34 \\
Vietcombank & 307.62 & 366.72 & 414.49 & 468.99 & 574.26 \\
Average size & 108.54 & 128.08 & 134.36 & 149.34 & N.A \\
\hline
\end{tabular}

Source: Bankscope database 


\section{Table 2}

Total assets of four large-sized banks in the world as of 2014 (in USDbil.)

\begin{tabular}{lc}
\hline Name of bank & Total assets \\
\hline Industrial and Commercial Bank of China & $3,328.48$ \\
China Construction Bank & $2,704.16$ \\
HSBC Holdings & $2,634.14$ \\
Agriculture Bank of China & $2,579.81$ \\
\hline
\end{tabular}

Source: Banks around the World (2014)

\subsection{Equity capital}

Recent years have witnessed an increase in banks' equity capital as oriented by the central bank. Due to business specifics, Vietnam's commercial banks are those using high debt balances, and many reveal a debt ratio of over $90 \%$. This fact indicates that self-protection among banking institutions is a concern, particularly in the context of the economic volatilities that significantly influence bank liquidity and competitiveness in the market.

\section{Table 3}

Equity-to-asset ratios for Vietnam's commercial banks (in \%)

\begin{tabular}{lccccc}
\hline Name of bank & 2010 & 2011 & 2012 & 2013 & 2014 \\
\hline Agribank & 4.82 & 4.92 & 5.67 & 5.23 & NA \\
Vietinbank & 5.00 & 6.23 & 6.72 & 9.42 & 8.36 \\
BIDV & 5.73 & 6.06 & 5.51 & 5.89 & 5.17 \\
Vietcombank & 6.78 & 7.85 & 10.06 & 9.07 & 7.72 \\
\hline
\end{tabular}

Source: Bankscope database

Increase in equity capital considerably improves capital adequacy ratios (CARs) for banking institutions in Vietnam, and CAR has a tendency to rise over the years. 


\section{Table 4}

Capital adequacy ratio for Vietnam's commercial banks (in \%)

\begin{tabular}{lcccc}
\hline Name of bank & 2011 & 2012 & 2013 & 2014 \\
\hline Agribank & 6.04 & 6.81 & 6.21 & NA \\
Vietinbank & 6.65 & 7.21 & 10.40 & 9.12 \\
BIDV & 7.76 & 6.89 & 7.87 & 7.84 \\
Vietcombank & 8.52 & 11.19 & 9.97 & NA \\
\hline
\end{tabular}

Source: Bankscope database

\subsection{Asset quality}

As with increase in bank size, credit growth rate of Vietnam's commercial banks is high. These banks, moreover, are affected by volatilities of macro factors, which result in a tendency for nonperforming loans to rise. Vietnam Asset Management Company (VAMC) came into operation, then acquiring banks' nonperforming loans, which in turn were drastically reduced. Nevertheless, the current mechanism of VAMC's operations merely contributes to temporary diminishing levels of nonperforming loans. Responsibility for arranging these loans still rests with those holding loan sales.

\section{Table 5}

Levels of nonperforming loans for Vietnam's commercial banks (in \%)

\begin{tabular}{lcccc}
\hline Name of bank & 2011 & 2012 & 2013 & 2014 \\
\hline Agribank & 6.10 & 5.80 & 7.56 & N.A \\
Vietinbank & 0.75 & 1.47 & 1.00 & 1.12 \\
BIDV & 2.76 & 2.69 & 2.26 & 2.03 \\
Vietcombank & 2.03 & 2.40 & 2.72 & 2.31 \\
Total average & 3.40 & 4.67 & 7.97 & N.A \\
\hline
\end{tabular}




\subsection{Profitability}

Bank profits have been well maintained; however, the yearly profit growth rate tends to drop as banks suffer economic difficulties as has been experienced domestically and internationally. The decline is perceived as uneven across the banking groups with different size.

\section{Table 6}

Return on assets (ROA) and return on equity (ROE) for Vietnam's commercial banks (in \%)

\begin{tabular}{lccccc}
\hline Name of bank & 2010 & 2011 & 2012 & 2013 & 2014 \\
\hline ROA & & & & & \\
Agribank & 0.43 & 0.42 & 0.43 & 0.18 & N/A \\
Vietinbank & 1.18 & 1.51 & 1.28 & 1.08 & 0.93 \\
BIDV & 1.04 & 0.83 & 0.67 & 0.78 & 0.83 \\
Vietcombank & 1.53 & 1.33 & 1.09 & 0.97 & 0.88 \\
Total average & 1.02 & 1.40 & 0.62 & 0.49 & 0.50 \\
\hline ROE & & & & & \\
Agribank & 13.57 & 8.61 & 8.12 & 3.36 & N/A \\
Vietinbank & 22.10 & 25.68 & 19.73 & 13.18 & 10.46 \\
BIDV & 23.67 & 13.07 & 11.59 & 13.73 & 15.13 \\
Vietcombank & 17.91 & 18.76 & 12.35 & 10.33 & 10.62 \\
Total average & 10.40 & 19.66 & 14.31 & 19.90 & 10.02 \\
\hline
\end{tabular}

\subsection{Technological level}

The successful implementation of the scheme on modernizing banking technology and payment systems under the World Bank funding has served to develop the national payment infrastructure, including the interbank electronic payment system, which enables Vietnam's banking institutions to uniformly manage their capital sources or to provide online payment services promptly and conveniently.

Although banks have paid rapt attention to investments in technological development to cater for specific banking activities, investments in upgrading and exploiting 
technological infrastructure seem disproportionate due to constraints of capital sources and ability to apply modern technologies. Typically, the interbank electronic payment system reveals certain shortcomings, failing to establish synchronous connections in the banking system in order to minimize the investment costs and provide useful services for customers.

\subsection{Human resources quality}

Personnel selection in the banking sector has been significantly made over the past years. In spite of an increasing demand for high-quality human resources, the supply of skillful workers do not sufficiently meet the requirements, thus causing irrational labor movements and a profound impact on the quality of bank human resources. Vietnamese banks have not adequately focused on frequent training for improving professional skills for their staff. Large-scales banks have the training divisions, which, however, have not satisfactorily performed their supporting role in banking activities.

\subsection{Operational management structure}

Despite macroeconomic fluctuations in these years, Vietnam's banking institutions successfully maintain their profitability as well as a decreasing rate of operating expenses. A compact management structure, coupled with centralized management techniques, greatly contributes to sharply reduce bank risks, which implies improvement in bank management effectiveness. However, in order to act in line with international standards, banks are supposed to make further efforts in improving their management practices.

\subsection{Business banking products}

Bank products and services are still simple and monotonous even though many banks have paid more attention to product diversification, which merely ends at increasing utility for traditional products. Hence, market research and development intended for product improvements should be further promoted to satisfy higher customer needs.

\subsection{Banking brand}

For many years Vietnamese banks have shifted their attention to market positioning. Some good examples include changing logos, establishing a unified brand identification system within the banking sector, and devising banking brand management regulations. Yet, a high degree of uniformity in business banking products, little focus on marketing 
activities, and ineffective communication strategies accounted for many difficulties in banking brand development.

\subsection{Bank competitiveness at a glance}

Based on the above analysis, a few implications can be drawn with regard to the overall competitiveness of Vietnamese banks as below:

First, bank size in Vietnam is very small, compared to that of foreign commercial banks. Specifically, the size of four large-sized banks in Vietnam is merely equivalent to that of medium-sized ones in the region, although great efforts have been made to raise capital in recent years from state funding, equitization of state commercial banks, more share issuance for joint-stock commercial banks, and other complementary capital sources.

Second, CARs are low and unevenly distributed, thus failing to meet the integration requirements for the banking sector. In the coming years capital increase continues to be a need to overcome the shortcomings in financial capacity.

Third, the need for high-quality human resources has yet to be met; the policy on attracting and retaining skilled and professional staff has not been adequately adopted, causing "brain drain" to foreign banks or other domestic sectors. This is such a major obstacle for Vietnamese banks to improve and enhance their competitiveness in the process of integration into the world economy.

Fourth, despite certain attempts to invest in technological development, efficiency in exploitation and/or use of technological advances is not great. Little harmony between different investment and exploitation strategies leads to wastefulness of technological investment schemes.

Fifth, managerial levels have been upgraded, yet the integration process requires that international standards be reached in the governance of banking institutions. Therefore, effective management practices remain a puzzle as for commercial banks in Vietnam.

In sum, the landscape of Vietnamese banking sector indicates that banks need to continuously minimize their weaknesses to enhance competitiveness in the long run in order to satisfy the demand for global integration and restructuring of the banking system. 


\section{Competition in the banking sector of Vietnam between 2005 and 2013}

\subsection{Earlier empirical studies on bank competition}

Panzar and Rosse (1987), in designing a test on monopoly, demonstrated that competitiveness can be explained in association with income elasticity and input prices. The result obtained from the so-called $\mathrm{H}$-statistic serves to indicate the existence of monopolistic competition in the banking industry.

Goddard and Wilson (2009) utilized the P-R model for a panel estimation in relation to bank competition among the banking sectors of the Group of Seven countries. The paper found that the input factors do exert effects on volatility in bank revenue ratios.

Rezitis (2010) examined the effect of merger and acquisition (M\&A) transactions on competition in Greek banking industry, showing that these kinds of transactions result in changes in bank competition and also the market power. Bank concentration with its higher degree is conducive to collusive behavior and monopolistic competition. Bank competitiveness is suggested to be influenced by various factors, such as the presence of foreign banks, the level of concentration of the banking sector, the competition policy, or the bank structure, etc.

Maudos and Solis (2011), using H-statistic and Lerner index, evaluated competition in the Mexican banking sector in the context of liberalization over 1993-2005 period. As evidenced by the empirical analysis, monopolistic competition exists among banking institutions in the country.

In an analysis of bank consolidation and the competitive structure of Korean banking industry, Shin and Kim (2013) indicated that bank competitiveness increases with higher levels of market concentration and that a higher extent of banking competition results from an increase in the sum of the elasticities of input prices. The input prices, as utilized by the authors, comprise those of labor, capital, and total funds.

\subsection{Research models}

\subsubsection{Variable description}

Adopting the $\mathrm{P}-\mathrm{R}$ model and following earlier non-structural approaches and empirical findings on the levels of competition in the banking sectors of various countries, such as Greece, Mexico, and Korea, this study aims to measure bank competitiveness and investigate the potential existence of monopolistic competition 
among Vietnam's banking institutions. In this respect a few variables are employed, including revenue-to-asset ratio, interest-income-to-asset ratio, price of capital, price of labor, price of fixed assets, market share of the bank, other revenue ratio, and loan loss reserve ratio (Table 7).

\section{Table 7}

Description of variables in the study

\begin{tabular}{lll}
\hline Notation & Definition & Measured by \\
\hline Dependent variables & & \\
TRA & Revenue-to-asset ratio & Total revenue/total assets \\
TIA & Interest-revenue-to-asset ratio & Interest revenue/total assets \\
& & \\
\hline Independent variables & & \\
PF & Price of capital & Interest expense/total deposits \\
& & \\
PL & Price of labor & Personnel expense/number \\
& & of \\
PK & Price of fixed assets & Customer expense and others/ fixed \\
& & assets \\
\hline
\end{tabular}

Control variables
A
Market share of the bank
Total assets of the bank/total assets of the banking system
$\mathrm{O}$
Other revenue ratio
Other revenue/total revenue
$\mathrm{R} \quad$ Loan loss reserve ratio Loan loss reserve expense/total
loans

As with the variables defined in Table 7, two simple regression equations with the use of TRA and TIA respectively are presented as follows:

$$
\begin{aligned}
& \ln T R A_{i t}=b_{0}+b_{1} \ln P F_{i t}+b_{2} \ln P L_{i t}+b_{3} \ln P K_{i t}+b_{4} A_{i t}+b_{5} O_{i t}+b_{6} \ln R_{i t}+\varepsilon_{i t} \\
& \ln T R A_{i t}=\alpha_{0}+\alpha_{1} \ln P F_{i t}+\alpha_{2} \ln P L_{i t}+\alpha_{3} \ln P K_{i t}+\alpha_{4} A_{i t}+\alpha_{5} O_{i t}+\alpha_{6} \ln R_{i t}+\varepsilon_{i t}
\end{aligned}
$$




\subsubsection{Model testing procedures}

Several steps are taken to obtain the research results as follows:

Step 1: Statistical description features a brief summary of mean value, maximum value, minimum value, and standard deviation of the data in use, including bank's input and output factors.

Step 2: Analysis of correlation matrix of the variables is performed to examine the correlations between dependent and independent variables and also between the independent variables in the models to detect the problem of multicollinearity among these variables.

Step 3: Estimations of regression coefficients is based on Pooled OLS, FEM, and REM, and the paper uses other tests, such as F-test, Hausman test, and Brush pagan test, for selecting the most appropriate model.

Step 4: A heteroskedasticity test is conducted for proper treatments (by using robust optimization or GLS techniques).

Step 5: Other tests are proposed to measure the levels of correlation between bank's input and output factors.

Step 6: Regression results are discussed besides evaluation of the state of competition among Vietnam's banking institutions over the two pre- and post-crisis periods.

\subsection{Research findings}

Data are extracted from the annual reports of Vietnam's commercial banks, those of the State Bank of Vietnam, and the Bankscope database. The data sample is collected for 25 banks (67 observations) and 28 banks (112 observations) for the two periods of 2005-2007 and 2010-2013 respectively. The 2008-2009 period is perceived as blue when the commercial banking system was strongly affected by the financial crisis, so that bank restructuring was urgently needed to stabilize banking activities. Within the scope of this study regression analysis is not performed for this period, which can be viewed as an intermediate stage for bank performance before and after the crisis, which in turn, in fact, should be discussed at length in relation to volatility in bank competitiveness. 


\section{The 2005-2007 period}

\section{Table 8}

Statistical description of the sample for the 2005-2007 period

\begin{tabular}{lccccc}
\hline Variable & Mean & Std. dev. & Min & Max & Obs. \\
\hline $\operatorname{lnTRA}$ & -2.66421 & 0.274992 & -3.66591 & -2.1303 & 67 \\
$\operatorname{lnTIA}$ & -2.79547 & 0.282523 & -3.66591 & -2.21223 & 67 \\
$\operatorname{lnPF}$ & -2.81309 & 0.240086 & -3.69445 & -2.24055 & 67 \\
$\operatorname{lnPK}$ & -0.30355 & 0.698811 & -2.09932 & 1.422303 & 67 \\
$\operatorname{lnPL}$ & -2.83747 & 0.465045 & -4.5526 & -1.66546 & 67 \\
A & 0.044776 & 0.070096 & 0.000245 & 0.287127 & 67 \\
O & 0.536447 & 2.339744 & 0.01105 & 14.74748 & 67 \\
$\operatorname{lnR}$ & -0.60308 & 1.155919 & -4.60517 & 1.957274 & 67 \\
\hline
\end{tabular}

\section{Table 9}

Regression results for TRA with different estimators (2005-2007)

\begin{tabular}{lcccc}
\hline Dependent variable: TRA & POOLED & FEM & REM & GLS \\
\hline PF & $0.580^{* * *}$ & 0.189 & $0.323^{* * *}$ & $0.671^{* * *}$ \\
\hline PK & $(4.69)$ & $(1.64)$ & $(2.95)$ & $(8.31)$ \\
\hline PL & -0.0289 & -0.0156 & 0.00637 & $-0.0766^{* *}$ \\
\hline A & $(-0.68)$ & $(-0.32)$ & $(0.15)$ & $(-2.54)$ \\
\hline O & -0.067 & 0.0513 & 0.00151 & $-0.125^{* * *}$ \\
\hline R & $(-0.91)$ & $(0.77)$ & $(0.02)$ & $(-4.98)$ \\
\hline & $1.975 * * *$ & $-2.839 *$ & 0.994 & $2.414^{* * *}$ \\
\hline & $(3.50)$ & $(-1.99)$ & $(1.40)$ & $(8.80)$ \\
\hline & 0.00354 & -0.0456 & 0.00432 & 0.00286 \\
\hline
\end{tabular}




\begin{tabular}{lcccc}
\hline Dependent variable: TRA & POOLED & FEM & REM & GLS \\
\hline Cons & $-1.288^{* * *}$ & $-1.849 * *$ & $-1.802 * * *$ & $-1.213^{* * *}$ \\
\cline { 2 - 4 } & $(-3.30)$ & $(-6.29)$ & $(-6.11)$ & $(-5.70)$ \\
\hline R-squared & 67 & 67 & 67 & 67 \\
\hline F-test & 0.387 & 0.237 & & \\
\hline Hausman test & & 0.0000 & & \\
\hline Breusch pagan test & & 0.0047 & & \\
\hline t-statistics in brackets & & & & \\
\hline$* \mathrm{p}<0.1, * * \mathrm{p}<0.05, * * * \mathrm{p}<0.01$ & & & & \\
\hline
\end{tabular}

The testing results for suitability of the estimators for the research sample are as follows: F-test $(\mathrm{p}$-value $=0.000)$, Hausman test $(\mathrm{p}$-value $=0.0047)$, and Brusch-Pagan test ( $\mathrm{p}$-value $=0.0002$ ), which suggests that FEM is the most appropriate for analyzing the variance in TRA between 2005 and 2007.

Wald test is conducted for the panel data. Prob $>\mathrm{chi}^{2}=0.0000$ indicates that in FEM model there exists the problem of heteroskedasticity.

The heteroskedasticity is treated with both robust optimization and GLS regression. The results show that all variables are significant at 1\% and 5\% levels; thus GLS estimator can be regarded as the most reliable for regression analysis of TRA as a dependent variable.

\section{Table 10}

Regression results for TIA with different estimators (2005-2007)

\begin{tabular}{lcccc}
\hline Dependent variable: TIA & POOLED & FEM & REM & GLS \\
\hline PF & $0.579 * * *$ & 0.146 & $0.292^{* *}$ & $0.642^{* * *}$ \\
\cline { 2 - 5 } & $(4.38)$ & $(1.22)$ & $(2.50)$ & $(7.75)$ \\
\hline PK & -0.0189 & -0.0133 & 0.0112 & $-0.0772 * *$ \\
\cline { 2 - 5 } & $(-0.42)$ & $(-0.26)$ & $(0.24)$ & $(-2.32)$ \\
\hline PL & -0.0889 & -0.00884 & -0.0623 & $-0.130^{* * *}$ \\
\hline
\end{tabular}




\begin{tabular}{|c|c|c|c|c|}
\hline Dependent variable: TIA & POOLED & FEM & REM & GLS \\
\hline & $(-1.13)$ & $(-0.13)$ & $(-0.95)$ & $(-4.27)$ \\
\hline \multirow{2}{*}{ A } & $1.733 * * *$ & $-3.324 * *$ & 0.883 & $2.132 * * *$ \\
\hline & $(2.88)$ & $(-2.24)$ & $(1.16)$ & $(8.12)$ \\
\hline \multirow{2}{*}{$\mathrm{O}$} & -0.00486 & -0.126 & -0.00631 & -0.00309 \\
\hline & $(-0.37)$ & $(-1.54)$ & $(-0.32)$ & $(-1.18)$ \\
\hline \multirow{2}{*}{$\mathrm{R}$} & $0.0627 * *$ & -0.0281 & 0.0193 & $0.0418 * *$ \\
\hline & $(2.18)$ & $(-1.11)$ & $(0.80)$ & $(2.57)$ \\
\hline \multirow{2}{*}{ Cons } & $-1.462 * * *$ & $-2.215^{* * *}$ & $-2.195 * * *$ & $-1.435 * * *$ \\
\hline & $(-3.51)$ & $(-7.27)$ & $(-6.97)$ & $(-6.85)$ \\
\hline $\mathrm{N}$ & 67 & 67 & 67 & 67 \\
\hline R-squared & 0.337 & 0.243 & 0.403 & 0.557 \\
\hline F-test & \multicolumn{3}{|c|}{0.000} & \\
\hline Hausman test & \multicolumn{3}{|c|}{0.0003} & \\
\hline Breusch pagan test & \multicolumn{4}{|c|}{0.0003} \\
\hline \multicolumn{5}{|l|}{ t-statistics in brackets } \\
\hline
\end{tabular}

Table 10 displays the regression results for TIA, suggesting that FEM is suitable and that its preliminary results can be used to analyze the variance in TIA for the 2005-2007 period.

Wald test with $\mathrm{Prob}>\mathrm{chi}^{2}=0.0000$ indicates that heteroskedasticity occurs for FEM estimation.

Similarly, robust optimization and GLS regression are employed. Five out of six variables are statistically significant, thus implying that GLS estimator is more reliable and can be appropriately used to analyze TIA for the 2005-2007 period. 


\section{Table 11}

Synthesis of estimated results for TRA and TIA (2005-2007)

\begin{tabular}{|c|c|c|}
\hline \multirow{2}{*}{ Dependent variables: TRA and TIA } & \multicolumn{2}{|c|}{ 2005-2007 } \\
\hline & TRA & TIA \\
\hline \multirow{2}{*}{$\mathrm{PF}$} & $0.671 * * *$ & $0.642 * * *$ \\
\hline & $(8.31)$ & $(7.75)$ \\
\hline \multirow{2}{*}{ PK } & $-0.0766^{* *}$ & $-0.0772 * *$ \\
\hline & $(-2.54)$ & $(-2.32)$ \\
\hline \multirow{2}{*}{ PL } & $-0.125^{* * *}$ & $-0.130 * * *$ \\
\hline & $(-4.98)$ & $(-4.27)$ \\
\hline \multirow{2}{*}{ A } & $2.414 * * *$ & $2.132^{* * *}$ \\
\hline & $(8.80)$ & $(8.12)$ \\
\hline \multirow{2}{*}{$\mathrm{O}$} & 0.00286 & -0.00309 \\
\hline & $(1.54)$ & $(-1.18)$ \\
\hline \multirow{2}{*}{$\mathrm{R}$} & $0.0428 * * *$ & $0.0418^{* *}$ \\
\hline & $(3.22)$ & $(2.57)$ \\
\hline & $-1.213 * * *$ & $-1.435 * * *$ \\
\hline Cons & $(-5.70)$ & $(-6.85)$ \\
\hline $\mathrm{N}$ & 67 & 67 \\
\hline R-squared & 0.3667 & 0.310 \\
\hline $\mathrm{H}$-statistic & 0.4694 & 0.4348 \\
\hline \multicolumn{3}{|l|}{ Wald test } \\
\hline$(\mathrm{H}=1)$ & 0.0000 & 0.000 \\
\hline$(\mathrm{H}=0)$ & 0.0000 & 0.000 \\
\hline
\end{tabular}




\section{The 2010-2013 period}

This period saw some further participation of a few banks in the banking sector, which improves the sampling to the total of 112 observations. Descriptive statistics suggest that the research sample also ensures the reliability of the estimated results.

Table 12

Statistical description of the sample for the 2010-2013 period

\begin{tabular}{lccccc}
\hline Variable & Mean & Std. dev. & Min & Max & Obs. \\
\hline $\operatorname{lnTRA}$ & -2.328 & 0.2454 & -2.796 & -1.781 & 112 \\
$\operatorname{lnTIA}$ & -2.391 & 0.2555 & -2.948 & -1.831 & 112 \\
$\ln \mathrm{PF}$ & -2.548 & 0.2712 & -3.234 & -1.941 & 112 \\
$\ln \mathrm{PK}$ & 0.2811 & 0.7988 & -1.98 & 3.0428 & 112 \\
$\ln \mathrm{PL}$ & -1.877 & 0.3187 & -2.639 & -1.311 & 112 \\
$\mathrm{~A}$ & 0.0356 & 0.0407 & 0.0034 & 0.1686 & 112 \\
$\mathrm{O}$ & 0.4727 & 2.0308 & 0.0006 & 12.04 & 112 \\
$\ln \mathrm{N}$ & 0.3953 & 0.4532 & -0.528 & 1.6214 & 112 \\
\hline
\end{tabular}

\section{Table 13}

Regression results for TRA with different estimators (2010-2013)

\begin{tabular}{lcccc}
\hline Dependent variable: TRA & POOLED & FEM & REM & GLS \\
\hline \multirow{2}{*}{ PF } & $0.636^{* * *}$ & $0.645^{* * *}$ & $0.641^{* * *}$ & $0.651^{* * *}$ \\
\cline { 2 - 5 } & $(10.05)$ & $(10.22)$ & $(10.67)$ & $(18.14)$ \\
\hline PK & $-0.0398^{*}$ & $0.0592^{*}$ & -0.017 & $-0.0352^{* *}$ \\
\cline { 2 - 5 } & $(-1.80)$ & $(1.74)$ & $(-0.68)$ & $(-2.47)$ \\
\hline PL & $0.323^{* * *}$ & $0.315^{* * *}$ & $0.329 * * *$ & $0.313^{* * *}$ \\
\cline { 2 - 5 } A & $(5.10)$ & $(4.04)$ & $(5.04)$ & $(8.95)$ \\
\hline O & $-0.903^{*}$ & $-5.529 *$ & $-1.027 *$ & $-0.687 * *$ \\
\cline { 2 - 5 } & $(-1.77)$ & $(-1.90)$ & $(-1.74)$ & $(-2.11)$ \\
\hline & 0.0024 & 0.0172 & 0.0012 & 0.00183 \\
\hline
\end{tabular}




\begin{tabular}{lcccc}
\hline Dependent variable: TRA & POOLED & FEM & REM & GLS \\
\hline $\mathrm{R}$ & $(0.31)$ & $(0.22)$ & $(0.12)$ & $(1.06)$ \\
\hline & $0.113^{* * *}$ & $0.0994^{*}$ & $0.117^{* * *}$ & $0.0932^{* * *}$ \\
\cline { 2 - 5 } Cons & $(2.94)$ & $(1.97)$ & $(2.90)$ & $(3.73)$ \\
\hline $\mathrm{N}$ & -0.105 & 0.0391 & -0.083 & -0.0789 \\
\hline R-squared & $(-0.50)$ & $(0.17)$ & $(-0.41)$ & $(-0.63)$ \\
\hline F-test & 112 & 112 & 112 & 112 \\
\hline Hausman test & 0.589 & 0.646 & 0.2213 & 0.3418 \\
\hline Breusch pagan test & & 0.003 & & \\
\hline
\end{tabular}

t-statistics in brackets

${ }^{*} \mathrm{p}<0.1, * * \mathrm{p}<0.05, * * * \mathrm{p}<0.01$

The estimated results suggest the suitability of FEM estimator, which can be applied to the analysis of TRA during 2010-2013.

Heteroskedasticity can be found with the use of FEM, but GLS regression in treating the problem generates better results. Thus, GLS is employed for TRA between 2010 and 2013.

\section{Table 14}

Regression results for TIA with different estimators (2010-2013)

\begin{tabular}{lcccc}
\hline Dependent variable: TIA & POOLED & FEM & REM & GLS \\
\hline PF & $0.670^{* * *}$ & $0.714^{* * *}$ & $0.691^{* * *}$ & $0.734^{* * *}$ \\
\cline { 2 - 5 } & $(9.87)$ & $(10.40)$ & $(10.57)$ & $(18.90)$ \\
\hline PK & -0.0185 & $0.0850^{* *}$ & 0.00114 & $-0.0332^{* *}$ \\
\cline { 2 - 5 } & $(-0.78)$ & $(2.30)$ & $(0.04)$ & $(-2.34)$ \\
\hline PL & $0.345^{* * *}$ & $0.371^{* * *}$ & $0.361^{* * *}$ & $0.349^{* * *}$ \\
\hline & $(5.07)$ & $(4.38)$ & $(5.17)$ & $(9.76)$ \\
\hline
\end{tabular}




\begin{tabular}{lcccc}
\hline Dependent variable: TIA & POOLED & FEM & REM & GLS \\
\hline A & $-1.505^{* * *}$ & $-5.855^{*}$ & $-1.644^{* * *}$ & $-1.546^{* * *}$ \\
\cline { 2 - 5 } O & $(-2.75)$ & $(-1.85)$ & $(-2.68)$ & $(-4.55)$ \\
\hline & 0.000599 & -0.0207 & -0.000572 & 0.000945 \\
\hline $\mathrm{R}$ & $(0.07)$ & $(-0.24)$ & $(-0.06)$ & $(0.54)$ \\
\hline Cons & $0.0961 * *$ & 0.087 & $0.102 * *$ & $0.103 * * *$ \\
\hline $\mathrm{N}$ & $(2.34)$ & $(1.58)$ & $(2.37)$ & $(3.69)$ \\
\hline R-squared & -0.0167 & 0.286 & 0.0644 & 0.174 \\
\hline F-test & $(-0.07)$ & $(1.12)$ & $(0.29)$ & $(1.34)$ \\
\hline Hausman test & 112 & 112 & 112 & 112 \\
\hline Breusch pagan test & 0.563 & 0.658 & 60.26 & 0.547 \\
\hline t-statistics in brackets & & 0.0058 & & \\
\hline$* \mathrm{p}<0.1, * * \mathrm{p}<0.05, * * * \mathrm{p}<0.01$ & & 0.0061 & & \\
\hline
\end{tabular}

Table 14 displays the results for different estimators, including FEM which is suggested to be the most suitable for analyzing TIA over the period of 2010-2013.

Likewise, FEM regression reveals the occurrence of heteroskedasticity, which is then overcome by using both robust optimization and GLS regression. The results achieved from GLS estimation are more reliable; therefore, it is selected as the single estimator for TIA in the same period. 


\section{Table 15}

Synthesis of estimated results for TRA and TIA (2010-2013)

\begin{tabular}{|c|c|c|}
\hline \multirow{2}{*}{ Dependent variables: TRA and TIA } & \multicolumn{2}{|c|}{ 2010-2013 } \\
\hline & TRA & TIA \\
\hline \multirow{2}{*}{$\mathrm{PF}$} & $0.651 * * *$ & $0.734 * * *$ \\
\hline & $(18.14)$ & $(18.90)$ \\
\hline \multirow{2}{*}{ PK } & $-0.0352 * *$ & $-0.0332 * *$ \\
\hline & $(-2.47)$ & $(-2.34)$ \\
\hline \multirow{2}{*}{ PL } & $0.313 * * *$ & $0.349 * * *$ \\
\hline & $(8.95)$ & $(9.76)$ \\
\hline \multirow{2}{*}{ A } & $-0.687 * *$ & $-1.546^{* * *}$ \\
\hline & $(-2.11)$ & $(-4.55)$ \\
\hline \multirow{2}{*}{$\mathrm{O}$} & 0.00183 & 0.000945 \\
\hline & $(1.06)$ & $(0.54)$ \\
\hline \multirow{2}{*}{$\mathrm{R}$} & $0.0932 * * *$ & $0.103 * * *$ \\
\hline & (3.73) & $(3.69)$ \\
\hline & -0.0789 & 0.174 \\
\hline Cons & $(-0.63)$ & $(1.34)$ \\
\hline $\mathrm{N}$ & 112 & 112 \\
\hline R-squared & 60.26 & 0.547 \\
\hline H-statistic & 0.928 & 1.049 \\
\hline \multicolumn{3}{|l|}{ Wald test } \\
\hline$[\mathrm{H}=1]$ & 0.2047 & 0.3860 \\
\hline$[\mathrm{H}=0]$ & 0.0000 & 0.0000 \\
\hline
\end{tabular}




\subsection{Discussion of research results}

\section{Table 16}

Synthesis of estimated results for TRA and TIA (2005-2007 and 2010-2013)

\begin{tabular}{|c|c|c|c|c|}
\hline \multirow{2}{*}{ Variable } & \multicolumn{2}{|c|}{$2005-2007$} & \multicolumn{2}{|c|}{ 2010-2013 } \\
\hline & TRA & TIA & TRA & TIA \\
\hline \multirow{2}{*}{$\mathrm{PF}$} & $0.671 * * *$ & $0.642 * * *$ & $0.651 * * *$ & $0.734 * * *$ \\
\hline & $(8.31)$ & $(7.75)$ & $(18.14)$ & (18.90) \\
\hline \multirow{2}{*}{ PK } & $-0.0766 * *$ & $-0.0772 * *$ & $-0.0352 * *$ & $-0.0332 * *$ \\
\hline & $(-2.54)$ & $(-2.32)$ & $(-2.47)$ & $(-2.34)$ \\
\hline \multirow{2}{*}{ PL } & $-0.125 * * *$ & $-0.130 * * *$ & $0.313 * * *$ & $0.349 * * *$ \\
\hline & $(-4.98)$ & $(-4.27)$ & $(8.95)$ & $(9.76)$ \\
\hline \multirow{2}{*}{ A } & $2.414 * * *$ & $2.132 * * *$ & $-0.687 * *$ & $-1.546 * * *$ \\
\hline & $(8.80)$ & $(8.12)$ & $(-2.11)$ & $(-4.55)$ \\
\hline \multirow{2}{*}{$\mathrm{O}$} & 0.00286 & -0.00309 & 0.00183 & 0.000945 \\
\hline & (1.54) & $(-1.18)$ & $(1.06)$ & $(0.54)$ \\
\hline \multirow{2}{*}{$\mathrm{R}$} & $0.0428 * * *$ & $0.0418 * *$ & $0.0932 * * *$ & $0.103 * * *$ \\
\hline & $(3.22)$ & $(2.57)$ & $(3.73)$ & $(3.69)$ \\
\hline \multirow[b]{2}{*}{ Cons } & $-1.213 * * *$ & $-1.435 * * *$ & -0.0789 & 0.174 \\
\hline & $(-5.70)$ & $(-6.85)$ & $(-0.63)$ & $(1.34)$ \\
\hline $\mathrm{N}$ & 67 & 67 & 112 & 112 \\
\hline R-squared & 0.3667 & 0.310 & 60.26 & 0.547 \\
\hline H-statistic & 0.4694 & 0.4348 & 0.928 & 1.049 \\
\hline \multicolumn{5}{|l|}{ Wald test } \\
\hline$[\mathrm{H}=1]$ & 0.000 & 0.000 & 0.2047 & 0.3860 \\
\hline$[\mathrm{H}=0]$ & 0.000 & 0.000 & 0.0000 & 0.0000 \\
\hline
\end{tabular}


Price of capital, as one input factor of the bank, exerts the most powerful impact on the elasticities of TRA and TIA (Table 16).

There is an increase in H-statistic for the pre- and post-crisis periods, implying that higher competitiveness can be observed as a result of the positive outcome of bank restructuring. Particularly, M\&A deals in the banking sector becoming increasingly common have reduced the number of banks while increasing bank size. Higher bank concentration, more modernized technology applications, and further compliance with Basel standards as reflected by large-sized banks' management practices are believed to introduce a few changes to the bank competitiveness in the market.

The accepted hypothesis $[\mathrm{H}=1]$, based on the testing results, for the two dependent variables TRA and TIA at 5\% level hints that there exists monopolistic competition in the Vietnamese banking sector.

In the context of deeper integration in the global market and more entry of foreign banks in the national market, Vietnam's banking institutions are expected to make major changes to their competitive behavior to be able to seize the initiative.

\section{Recommendations for improving bank competitiveness until 2020}

\subsection{In respect of competitiveness among Vietnam's commercial banks}

First, continue to enhance financial capability of commercial banks by: (i) restructuring small-sized ones with poor financial health to expand their scope of operations (the process involves ensuring efficient M\&A in banking transactions in association with adjustments to banking activities after M\&A process for effective use of resources and making efficacious use of various funding sources from organizations and individuals for the costs of input have a profound impact on the volatility of earnings); (ii) upgrading credit quality to allow for interest income which accounts for a large proportion to the total bank income (this requires that banks implement stricter credit risk management, adopt long-term risk management strategies, completely handle the problem of outstanding debts, and frequently inspect unprofitable asset items to reduce losses and improve the asset quality; and (iii) pursuing effective strategies of liquidity risk management by proper controls over and good use of capital sources in the economy. 
Second, continue to implement diversification of bank products and/or services by: (i) renewing business products on the basis of modern technological applications to enhance product utilization to meet the integration demands from the banking sector; (ii) combining the promotion of traditional products/services with new product development such as expanding the supply package of banking products; (iii) focusing on developing personal banking services, which has great potential of growth in the market of more than 90 million Vietnamese citizens; (iv) promoting products with high technological content and significant features to make a striking difference; and (v) taking advantage of new distribution channels for diversified products and expanding consumer credit services.

Third, devise a strategy to attract and foster human resources; an effective strategy should also stress more on enhancing their quality, and this involves: (i) applying modern information technology in human resources management (evaluation of employee competency should include standards of professional ethics and work efficiency as a primary measure, along with great respect for talents for the productive use of high-quality human resources); and (ii) carrying out recruiting policy appropriate to the bank-specific characteristics with regard to investment in future human resources, adequate remuneration, favorable working environment, and periodic professional training.

Fourth, invest in and efficiently exploit banking technologies in harmony with business specifics and modernization, which facilitate modernity, safety, rapidity, and convenience of banking services.

Fifth, concerning bank managers, strengthen managerial capability while ensuring its scientific and artistic qualities by means of standardized systems or customer-centered approaches in accordance with international norms.

\subsection{In respect of competition among Vietnam's banking institutions up to 2020}

First, issue detailed regulations on the do's and don'ts to establish controls over unhealthy competition.

Second, adopt policies to curb monopoly or dominating position in the banking sector, which should not bias large-sized or previously state-owned banks against others.

Third, relocate banking offices to avoid uneven distribution density and undesirable behaviors in attracting customers. 
Fourth, encourage a shift of banks from multifunctional business to financial corporation practices to strictly comply with general and specific competition laws.

Fifth, implement stricter legal frameworks that separate the managerial function of state bank from the state financing role in banking activities.

\section{Concluding remarks}

From the theoretical bases with regard to bank competition and empirical findings from domestic and foreign investigations into competitiveness as well as the competitive banking environment, this study has pinpointed the issue in association with Vietnam's commercial banks. The results suggest certain improvements in the competitiveness of Vietnamese banks in recent years, yet compared with foreign banking institutions, it is still limited, thereby requiring that banks proceed to implement solutions to increasing their competitiveness until 2020. Competition in the banking sector reflects the existence of monopoly and dominating positions; thus, there is a need for a change toward confining monopolistic competition and bolstering healthy competition, which promotes better competitiveness among the banks in the market

\section{References}

Ariss, R. (2009). Competitive behavior in Middle East and North Africa banking systems. The Quarterly Review of Economics and Finance, 49, 693-710.

Banks around the World. (2014). Top banks in the world 2014. Retrieved from http://www.relbanks.com/worlds-top-banks/assets-2014

Biekpe, N. (2011). The competitiveness of commercial banks in Ghana. African Development Review, 23(1), 75-87.

Goddard, J., \& Wilson, J. (2009). Competition in banking: A disequilibrium approach. Journal of Banking and Finance, 33(12), 2282-2292.

Hempell, H. S. (2002). Testing for competition among German banks (Discussion Paper 04/02). Germany: Economic Research Centre of the Deutsche Bundesbank.

Hondroyiannis, G., Lolos, S., \& Papatrous, E. (1999). Assessing competitive conditions in the Greek banking system. Journal of International Financial Markets, Institutions and Money, 9, 371-391.

Maudos, J., \& Solis, L. (2011). Deregulation, liberalization, and consolidation of the Mexican banking system: Effects on competition. Journal of International Money and Finance, 30, 337-353. 
Panzar, J., \& Rosse, J. N. (1987). Testing for monopoly equilibrium. The Journal of Industrial Economics, 35(4), 443-456.

Porter, M. E. (1980). Competitive strategy. NY: The Free Press.

Porter, M. E. (1985). Competitive advantage. NY: The Free Press.

Rezitis, A. (2010). Evaluating the state of competition of Greek banking industry. Journal of International Financial Markets, Institutions and Money, 20, 68-90.

SBV. (2010). Annual report of 2010 (in Vietnamese). Hanoi, Vietnam: State Bank of Vietnam.

SBV. (2011). Annual report of 2011 (in Vietnamese). Hanoi, Vietnam: State Bank of Vietnam.

SBV. (2012). Annual report of 2012 (in Vietnamese). Hanoi, Vietnam: State Bank of Vietnam.

SBV. (2013). Annual report of 2013 (in Vietnamese). Hanoi, Vietnam: State Bank of Vietnam.

Shin, D. J. (2007). The degree of competition of banking industry and policy implication (Economic Issue Brief, No. 25). Seoul, Korea: Korean National Assembly Budget Office.

Shin, D. J., \& Kim, B. H. S. (2013). Bank consolidation and competitiveness: Empirical evidence from the Korean banking industry. Journal of Asian Economics, 24, 41-50.

Vietnamese Government. (2006). Decision No. 112/2006/QD-TTg approving the scheme on development of Vietnam's banking sector up to 2010 and orientations toward 2020 (in Vietnamese). Retrieved from http://thuvienphapluat.vn 